\title{
STUDY OF NITRATE ADSORPTION CHARACTERSTICS ON RED SOIL
}

\author{
Shashikant.R.Mise ${ }^{1}$, Ramesh Bashetty ${ }^{2}$ \\ ${ }^{1}$ Professor, Department of Civil Engineering, ${ }^{2}$ Assisstant Professor, Department of Civil Engineering, \\ PDA College of Engineering Gulbarga \\ srmise45@yahoo.com,Ramesh.syn@gmail.com
}

\begin{abstract}
In this research, adsorption of Nitrate (N-Adsorption) on Red soil has been studied through using batch adsorption techniques. Main objectives of this study are, to study the physical properties of Red soil, detection of Nitrate removal by adsorbent as a function of contact time, adsorbent dosage and $\mathrm{pH}$, to study sorption kinetics. The results of this study showed that the Optimum contact time, dosage and $\mathrm{pH}$ for adsorption of Nitrate on Red soil reached to equilibrium after 130mins, with removal efficiency of (86\%), 1400mg as optimum dosages. Higher adsorption of Nitrate was observed at higher $p H$, obtained at $\mathrm{pH} 6.0$, the rate of adsorption of Nitrate obeys first order rate equation. The obtained results of the batch experiments are best fit to Langmuir and Freundlich adsorption isotherms. From the experimental analysis it is concluded that Red soil shows good removal efficiency and hence can be used as adsorbents.
\end{abstract}

Keywords: N-Adsorption, characteristics, Batch Experiments, Freundlich Isotherm, Langmuir Isotherm. ***

\section{INTRODUCTION}

For the first time in this entire cultural history, man is facing one of the most horrible ecological crises - the problem of pollution of his environment, which in the past was pure, virgin, undisturbed, uncontaminated, and basically quite hospitable for him [1]. Waste disposal from various industries, municipal dumping in the urban areas and increased use of chemical fertilizers, pesticides and irrigation water are of great environmental concern. The residues of fertilizers, pesticides and irrigation water in one hand, increased agricultural production; while, on the other hand, created adverse impact on soil and water bodies [1]. Under natural conditions, lakes, rivers, and other water bodies undergo Eutrophication, an aging process that slowly fills in the water body with sediment and organic matter.

When these sediments enter various bodies of water, fish respiration becomes impaired, plant productivity and water depth become reduced, and aquatic organisms and their environments become suffocated. Pollution in the form of organic material enters waterways in many different forms as sewage, as leaves and grass clippings, or as runoff from livestock feedlots and pastures. When natural bacteria and protozoan in the water break down this organic material, they begin to use up the oxygen dissolved in the water. Many types of fish and bottom-dwelling animals cannot survive when levels of dissolved oxygen drop below two to five parts per million. Animal wastes are high in oxygen demanding material, nitrogen and phosphorus, and they often harbor pathogenic organisms [2].
In our area available soils are Red soil, Black cotton soil. The objectives of the work are, to study the retention and leaching of different types of soils available in the area, mainly Red soil. Determining the maximum amount of Nitrate adsorbed under mono element condition, and to evaluate the potentials for these mineral to migrate through these soils during groundwater percolation. To perform a set of Batch experiments to obtain Retardation factors for Nitrate for the above mentioned soil by fitting the experimental results to analytical equations given by Langmuir and Freundlich isotherms.

Rajkishore Patel and Mahamudur Islam (Oct 2008) studied the "Nitrate sorption by thermally activated $\mathrm{Mg} / \mathrm{Al}$ chloride hydrotalcite-like compound" And it has been reported that the removal of nitrate was $87.6 \%$ under neutral condition, using $0.3 \mathrm{~g}$ of adsorbent in $100 \mathrm{~mL}$ of nitrate solution having initial concentration of $10 \mathrm{mg} / \mathrm{L}$. Adsorption kinetic study revealed that the adsorption process followed first-order kinetics. Adsorption data were fitted to linearly transformed Langmuir isotherm with R2 (correlation coefficient) $>0.99$

\subsection{Objectives of the study}

- To study the retention (sorption and/or chemically inactive) and leaching of Nitrate in soils with available in the area as Red soil.

- Determining the maximum amount of Nitrate adsorbed under mono element condition, and to 
evaluate the potentials for these mineral to migrate through Red soil during groundwater percolation.

- To perform a set of batch experiments to obtain retardation factors for Nitrate for the above mentioned Red soil by fitting the experimental results to analytical equations given by Langmuir and Freundlich isotherms.

\section{MATERIALS AND METHODS}

\subsection{Material}

Sample of Red soils is available from different locations in Bidar district and some of red soil sample is collected near humanabad taluka and this sample is taken and tested. The Red soil is moderately acidic in nature.

\subsubsection{Characteristics of Red soil:}

Before using the Red Soil as an adsorbent, the characteristics such as moisture content, ash content, $\mathrm{pH}$, decolorizing power, surface area, specific gravity and bulk density of the prepared carbon are studied. The results are shown in Table 1

All the methods of analysis are as per "Standard Methods for the Examination of Water and Wastewater", 19th edition. [3]

Table 1 Characteristics of Red soil

\begin{tabular}{|l|l|l|}
\hline S1.No. & Characteristics & Red soil \\
\hline 1 & Sand fraction & 24.36 \\
\hline 2 & Gravel fraction & 0 \\
\hline 3 & $\begin{array}{l}\text { Clay fraction Silt+ } \\
\text { fraction }\end{array}$ & 75.64 \\
\hline 4 & $\begin{array}{l}\text { Soil bulk density } \\
\text { Kg/m3) }\end{array}$ & 1141 \\
\hline 5 & pH & 7.74 \\
\hline 6 & Porosity & 0.6 \\
\hline 7 & Soil texture & clay \\
\hline
\end{tabular}

\subsection{Methods}

\subsubsection{Batch Sorption Experiment}

In batch sorption, a predetermined amount of adsorbent is mixed with the sample. The sample is shaking on a rotary shaker for a given contact period and subsequently separated by filtration. Powdered adsorbent is more suitable for the batch type contact process.

Nitrate removal affinity of Red soil was determined from batch experiments as a contact time, dose of the adsorbent, $\mathrm{pH}$, kinetics of Nitrate removal were also studied.

\subsubsection{Selection of Optimum Contact Time:}

The adsorption is strongly influenced by the contact time, for the study of effect of contact time $100 \mathrm{~m} 1$ of $10 \mathrm{mg} / \mathrm{L}$ Nitrate solution was mixed with $50 \mathrm{gm}$ of soil sample and stirred for different period of contact time i.e. for $2 \mathrm{hr}$ and time interval varies as $3,5,10,20 \ldots \ldots 150 \mathrm{~min}$.This is filtered and analyzed for Nitrate concentration using spectrophotometer method.

\subsubsection{Determination of Optimum Dosage of}

\section{Adsorbent:}

To determine the optimum dosage of adsorbent, adsorbents were added to the conical flask containing known concentration of Nitrate solution $(10 \mathrm{mg} / \mathrm{L})$. The solution in the conical flask was subjected to stirring for optimum contact time and the dosage varies from 200,400,600 ....1200mg/L. Filtered and analyzed for residual and removal of Nitrate concentration. The dosage which gives minimum residual concentration is chosen as optimum dosage.

\subsubsection{Selection of Optimum pH:}

To determine the optimum $\mathrm{pH}$ series of conical flasks were taken with $100 \mathrm{ml}$ of $10 \mathrm{mg} / \mathrm{L}$ Nitrate solution. Optimum dosage of soil $(10 \mathrm{mg} / 100 \mathrm{ml})$ is added the $\mathrm{pHs}$ of the flasks were adjusted ranging from 2.5 to 8.0. The flasks were shaken for optimum contact time. After stirring the samples are filtered and analyzed for the residual Nitrate concentration. The flask which gives minimum residual concentration is selected as the optimum $\mathrm{pH}$.

\subsubsection{Adsorption Isotherms}

The quantity of adsorbate that can be taken up by an adsorbent is a function of both the characteristic and concentration of adsorbate and the temperature. The characteristic of the adsorbate that are of importance include: solubility, molecular structure, molecular weight, polarity and hydrocarbon saturation. Generally the amount of adsorbate adsorbed by adsorbent is determined as the function of concentration at constant temperature, and the resulting function is called as the adsorption isotherm.

Adsorption isotherms are developed by exposing a given amount of adsorbate in a fixed volume of liquid to varying amounts of adsorbate. Equations that are often used to describe the experimental isotherm data were developed by Freundlich and Langmuir.

\section{RESULTS AND DISCUSSIONS}

The efficiency of removal of nitrate is studied in terms of:

a) Effect of contact time

b) Effect of dosage

c) Effect of $\mathrm{pH}$ 


\subsection{Effect of Contact Time:}

Contact time has great influence on the adsorption process. The effects of contact time on the adsorptions of Nitrate were calculated. From the figure it is observed that the extent of Nitrate adsorption increases with increase in time and attain equilibrium at particular time. The adsorption curves are characterized by sharp rise initial stage and decrease near equilibrium. From the graph after equilibrium further increase in time adsorption is not changing hence for Red soil is 130mins. Shown in the fig. 1

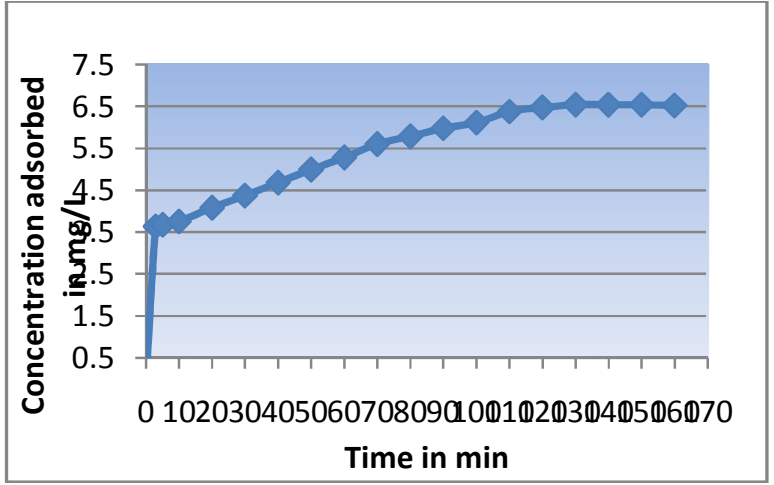

Fig.1. Effect of contact time of Nitrate in Red soil.

\subsection{Effect of Adsorbent Dosage:}

Adsorption is a process in which there is continuous transfer of solute from solution to adsorbent until residual concentration of solution maintains equilibrium with that adsorbed by the surface of adsorbent at constant contact time. Effect of adsorbent dosage is studied and graph of Nitrate removal verses dosage is plotted as shown in fig. 2 from the graph it is observed that, as the dose Red soil increases, amount of residual Nitrate decreases sharply and attains minimum.

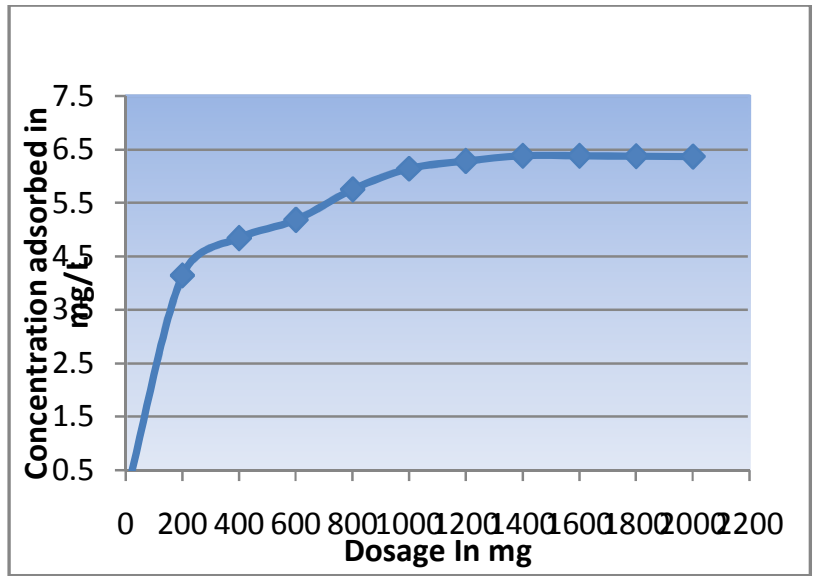

Fig.2.Effect of Adsorbent Dosage of nitrate in red soil

\subsection{Effect of pH:}

The impact of Nitrate removal is depends on $\mathrm{pH}$ of the medium. The graph of $\mathrm{pH}$ against Nitrate removal at constant time and dosage is shown in fig. 3 , the values of $\mathrm{pH}$ and corresponding Nitrate adsorbed are shown in table. It is observed from the graph that, Nitrate removal is not only depends on surface area, time and dosage but also depends on $\mathrm{pH}$

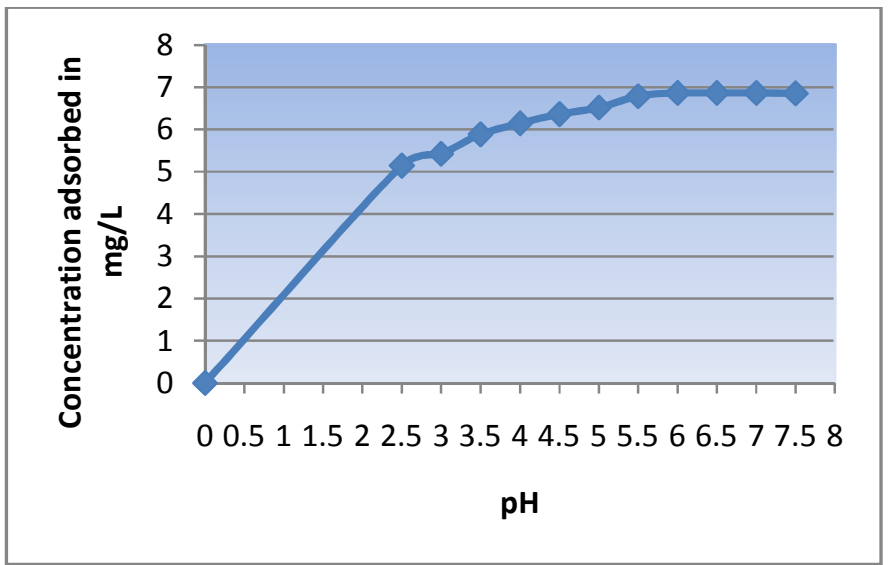

Fig.3. Effect of pH of Nitrate in Red soil

\section{SINGLE ADSORPTION OF NITRATE (BATCH EXPERIMENT)}

\subsection{Red Soil}

Table 2 Single adsorption of Nitrate in Red Soil

\begin{tabular}{|l|l|l|l|}
\hline $\begin{array}{l}\mathrm{C} \\
\mathrm{mg} / \mathrm{L}\end{array}$ & $\mathrm{Q} \mathrm{mg} / \mathrm{kg}$ & $\begin{array}{l}1 / \mathrm{C} \\
1 / \mathrm{mg}\end{array}$ & $\begin{array}{l}1 / \mathrm{Q} \\
\mathrm{kg} / \mathrm{mg}\end{array}$ \\
\hline 10 & 62.75 & 0.1 & 0.01556 \\
\hline 15 & 80.80 & 0.0666 & 0.01298 \\
\hline 20 & 117.6 & 0.04 & 0.00641 \\
\hline
\end{tabular}

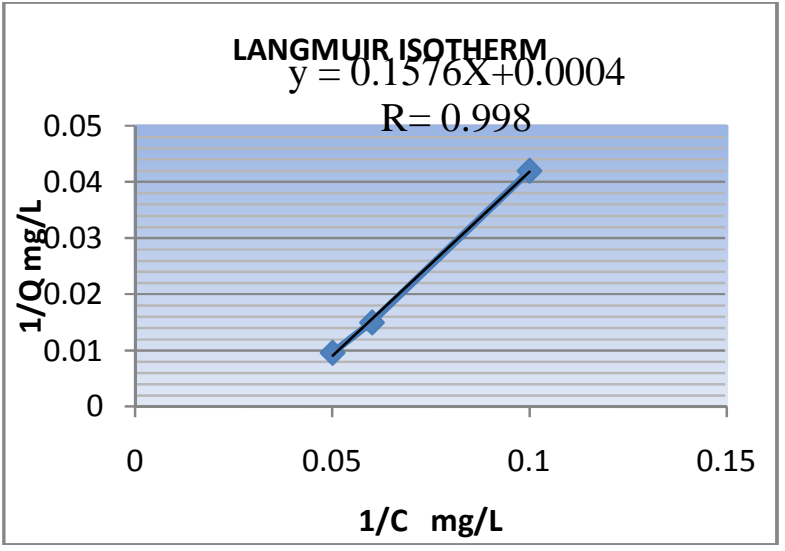

Fig. 4 Single adsorption of Nitrate in Red Soil 


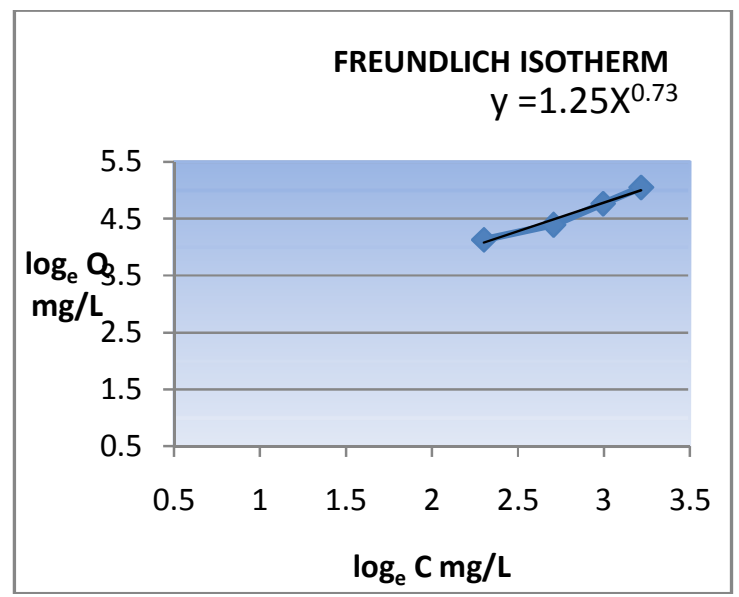

Fig.5 Single adsorption of Nitrate in Red Soil

\section{CONCLUSIONS}

Based on the experimental study the following conclusions were drawn. The extent of Nitrate adsorption increases with increase in time and attain equilibrium. The result of experiment on optimization of dosage the adsorbent reveals that increase in amount of adsorbent added, increases the removal of nitrate from the solution and almost becomes constant after saturation dose for different dosages. The adsorption of Nitrate is $\mathrm{pH}$ dependent. The removal efficiency of adsorbent increases with decrease in the $\mathrm{pH}$ value 6 . In batch experiments studies the adsorption of nitrate follows Freundlich and Langmuir isotherms indicating single adsorption of nitrate and proves to be a favorable $(\mathrm{R}=0.998)$ adsorption because when we fit the results to isotherms it gives equilibrium parameter or separation factor $\mathrm{R}<1$.

\section{REFERENCES}

[1] M.Del Bubbaa,, C.A. Ariasb, H. Brixc A Department of Chemistry, University of Florence, Via della Lastruccia 5, Sesto Fiorentino,

[2] Islam, M.S. et al. Retention of nitrate and phosphate in soil and their subsequent uptake by plants". Bangladesh J. Sci. Ind. Res 43(1), 67-76, 2008. Miller, R.W. and Donahue R.L. (1990) An Introduction to Soils and Plant Growth. (6th ed.) Prentic - Hall, Inc., Englewood Cliffs, New Jersey, U. S. A. 537-74.

[3] APHA manual "Standard methods for water and wastewater" (APHA AWWA Washington D C) (1996) pp 126-129 